\title{
Main Trends in the Digital Transformation of the Prosecutor's Office and the Organization of Its Activities
}

\author{
Alexander Moiseev ${ }^{1, *}$ Valentina Moiseeva ${ }^{1}$ Nailya Danilina ${ }^{1}$ \\ ${ }^{1}$ Togliatti State University, Togliatti 445020, Russian Federation \\ ${ }^{*}$ Corresponding author. Email: ur63@yandex.ru
}

\begin{abstract}
The relevance of the digital transformation of the prosecutor's office and the organization of its activities is due to the digitalization processes that permeate all spheres of public life. In modern legal reality, digital technologies are increasingly used through the introduction of information and analytical systems, robotic services capable of performing certain functions. The Prosecutor's Office of the Russian Federation is no exception, using more than thirty state and departmental information systems. The purpose of the article was to study the main trends in the implementation of key measures of the Concept of Digital Transformation of Bodies and Organizations of the Prosecutor's Office until 2025. The article considered such measures aimed at the digital transformation of the prosecutor's office, such as the creation of a single secure data transmission network, the introduction of special software of the GAS PS, the creation and transition of the prosecutor's office to electronic document flow, the integration of the FSIS "Unified Register of Inspections" with GAS "Management" and FSIS "Unified portal of state and municipal services (functions)", legal regulation of the state automated system of legal statistics. At the end of the article, it was concluded that the positive trends in the digitalization of the prosecution authorities do not exclude the need to improve the qualifications of digital transformation commissioners in the prosecution authorities of the Russian Federation.
\end{abstract}

Keywords: Digitalization, digitalization of law enforcement, digital transformation of prosecutors, electronic document management, digital technologies, information and analytical systems.

\section{INTRODUCTION}

The digitalization of public authorities is becoming a modern reality. The states adopt the corresponding necessary program documents. The use of digital technologies by public authorities is becoming the subject of scientific research by both domestic and a number of foreign researchers. Brown and Toze [1], Jones [2], Cargnello and Flumian [3] focus on the study of the process of implementing the concept of the "Era of digital control". Hood, in connection with the increasing role of the digital state, develops the doctrinal components of the new state administration [4]. Swan substantiates the organization of personalization of public services through digital technology such as blockchain [5]. Modern domestic scientists are exploring foreign experience in the implementation of blockchain systems in various areas of public administration [6].

Modern legal activity is characterized by an increasing use of digital technologies due to the introduction of information and analytical systems, robotic services capable of performing certain functions (to issue statements of claim, claims, draw up contracts, check transactions for compliance with laws, etc.). It became possible to apply via the Internet to the arbitration court and some district courts. Discussion of issues on reducing law enforcement to the "blockchain" procedure and automated consideration of some simple categories of cases, i.e. using artificial intelligence [7, pp. 277-281]. Such a rapid digitalization of law enforcement is associated with the need to quickly make competent decisions based on the analysis of a large amount of information in the dynamic conditions of the modern economy and human activity in all spheres of public life.

A number of policy documents adopted by state authorities are aimed at solving these issues, including, first of all, the Strategy for the Development of the Information Society in the Russian Federation for 20172030. [8], the Program "Digital Economy of the Russian Federation" [9], which became invalid on February 12, 2019 [10] and instead of which, the Presidium of the Council under the President of the Russian Federation for Strategic Development and National Projects on June 4, 2019 approved the National Program "Digital economy of the Russian Federation" [11].

In addition to general documents aimed at the development of digitalization, in certain areas of activity, legal regulation of a narrower order is also carried out. The Prosecutor's Office of the Russian Federation is no exception, carrying out a public function of supervision over the observance of the Constitution of the Russian Federation and the implementation of laws (Article 1 of the Federal Law "On the Prosecutor's Office of the Russian Federation" [12]). Currently, the Prosecutor's Office of the Russian Federation uses more than thirty state and departmental information systems, which af- 
fects the quality and efficiency of its supervisory activities in the context of the variety and efficiency of tasks and the increasingly complex prosecutorial activities in general.

\section{DIGITAL LEGAL TRANSFORMATION}

The Concept of Digital Transformation of Bodies and Organizations of the Prosecutor's Office of the Russian Federation until 2025 [13] (hereinafter - the Concept) is aimed at improving information support, comprehensive optimization of the internal activities of the prosecutor's office, the formation and development of a digital environment, a digital ecosystem of prosecution authorities.

The Concept sets goals for the digital transformation of the prosecutor's office, including not only increasing the efficiency of the prosecutor's office to ensure the rule of law, unity and strengthening the rule of law, but also increasing the information security of the prosecutor's office, developing its own digital infrastructure. The Concept outlines the principles in accordance with which the digital transformation of the prosecution authorities takes place: optimization, consolidation, reliability, standardization, a single data model, unification, virtualization, modularity, import substitution, information security.

The Concept identifies the creation of high-tech supervision, digital infrastructure and an environment of trust as the main directions of digital transformation of the prosecutor's office.

The purpose of this article is to investigate the main trends in the implementation of key activities within the main areas of digital transformation of prosecutors.

In order to implement the Concept of digital transformation of the prosecutor's office, on February 8, 2018, a joint order of the General Prosecutor's Office of the Russian Federation and the Ministry of Communications and Mass Media of the Russian Federation No. 68/56 (hereinafter - Order No. 68/56) was adopted [14]. This document is aimed at improving information support and increasing the efficiency of the activities of the prosecutor's office of the Russian Federation.

Achievement of the goal of digital transformation of the prosecution authorities is expected through the open publication of statistical data on the state of crime on a public portal on the Internet, reducing the time for receiving requests to the performer to 1 day, considering all requests in electronic form, providing prosecutors with a maximum of available information systems.

In order to implement Order No. 68/56, collegial project management bodies were formed in the prosecutor's office - the Project Committee and the Project Of- fice, whose activities are aimed at implementing the activities stipulated by the Concept.

\section{MAIN STEPS AND MEASURES}

Over the entire period of the Concept, a number of measures have been implemented for the digital transformation of the bodies and organizations of the prosecutor's office, among which the following can be distinguished.

Firstly, the lack of communication channels to the prosecutor's offices of the district and city level was compensated for by creating a unified secure data transmission network (hereinafter - EZSPD), which is in trial operation.

The EZSPD implements two independent segments with a different class of information protection. In departmental information systems, a closed loop of the EZSPD is implemented. In addition, as a common data transmission infrastructure, EZPSD provides centralized secure access to the Russian state segment of the Internet information and telecommunications network. In 2018, structured cable networks were built in 292 prosecutors' offices, the construction of which is planned to be completed in 2020 [15].

More than 3 thousand automated workstations with software are connected to the EZSPD, through which video conferences are held. It is planned to completely replace the park of automated workplaces by the end of 2021 [15].

Secondly, one of the directions of the transition of prosecutors to a digital work environment is the introduction of special software for the state automated system of legal statistics (hereinafter - GAS PS), which should contribute to a radical change in the collection and processing of legal statistics.

As for the GAS PS portal itself, at present it has improved and unified user interfaces, as well as developed new functionalities.

Thus, the component "typical violations" has been improved, which allows to ensure control over the reliability and timeliness of the provision of statistical information. This component automatically generates lists of criminal cases, primary accounting documents.

The "Free search" mode allows one to find information in a combination of any requisites of various forms of statistical cards. In addition, the ability to search for the necessary information by phrases or several words has been expanded, which is widely used in the preparation of analytical documents.

In personal accounts, it became possible to register criminal cases with the assignment of a unique number 
to them according to the uniform numbering rules in force on the territory of the Russian Federation.

Based on the information entered into the web interface of the user's personal account on the GAS Software portal, it became possible to generate primary accounting documents. This interface allows you to enter data directly on procedural actions and by filling in the fields that reflect the statistical information to be recorded. All this makes it possible for the user to focus on entering new information on a criminal case, rather than determining which statistical cards and in what volume he should fill out. All this reduces the labor and time costs of both prosecutors and other law enforcement agencies.

In addition, on the basis of the GAS PS, it is planned to create and implement a legally significant electronic document circulation and ensure its integration with the interdepartmental electronic document circulation system of a single interdepartmental digital online platform for interaction between prosecutors and heads of state bodies at all levels.

The General Prosecutor's Office of the Russian Federation has developed an action plan for the implementation of the GAS PS in all prosecutor's offices of the constituent entities of the Russian Federation in 20192021.

Third, the prosecutor's office is moving to electronic document management, for which the AIC "Supervision-WEB" subsystem has been created, which increases the throughput of processing requests and complaints, and thereby reduces the waiting time for feedback.

Trial operation of the AIC "Supervision-WEB" subsystem is carried out in a number of prosecutors' offices in Novgorod, Pskov, Rostov, Chelyabinsk regions, the Volga transport prosecutor's office and in subdivisions of the General Prosecutor's Office of the Russian Federation [15]. The start of operation of "SupervisionWEB" in the central office of the prosecutor's office began on August 5, 2019.

With the introduction of the AIC "SupervisionWEB" subsystem in the central office of the General Prosecutor's Office, paper statistical cards for appeals were abolished. The report on work with appeals and complaints of citizens is kept in electronic form using this subsystem [16].

In general, this is the first step for the transition to electronic document management and the connection of the prosecutor's office to the FSIS "Single portal of state and municipal services (functions)".

Fourthly, the program "Reform of control and supervisory activities" is implemented through the inte- gration of FSIS "Unified Register of Inspections" with GAS "Management" and FSIS "Unified Portal of State and Municipal Services (Functions)". The functionality of the federal state information system "Unified Register of Inspections" (hereinafter - FSIS ERP) is being expanded.

Trial operation of the software that implements the functions of filing an appeal and making an appointment with the prosecutor's office using the Unified Portal of State and Municipal Services in the prosecutor's offices of the city of Moscow, Novgorod and Pskov regions is being carried out.

It is assumed that by 2025 , the time it takes for applications to reach the contractor should be reduced to 1-2 days, and the share of their consideration should reach $100 \%$.

In order to ensure a prompt response to the facts of violations of the rights of business entities, by order of the Prosecutor General of the Russian Federation of September 19, 2019 No. 665, the Regulation was approved, which determines the procedure for considering complaints from business entities received through a specially created digital platform in connection with the pressure exerted on them by law enforcement organs [17].

The implementation of these measures will create conditions for convenient and transparent interaction of the prosecutor's office with citizens and entrepreneurs, and as a result - the effective implementation of their tasks by prosecutors.

Fifth, the digital transformation of the prosecutor's office is carried out on the basis of legal regulation implemented in the state automated system of legal statistics and the federal state information system "Unified Register of Inspections".

Trial operation of the GAS PS is carried out in 27 prosecutor's offices of the constituent entities of the Russian Federation and in the Main Military Prosecutor's Office. During the period of trial operation, the SAS PS processed 9.2 million statistical cards, registered 1.3 million criminal cases on the fact of 1.4 million crimes, 697.3 thousand victims of criminal encroachments and 604.2 thousand suspects, accused in the commission of crimes. The unified data warehouse contains information on 11.3 million registered reports of crimes [18].

To ensure the timeliness of accounting for statistical information and reduce the time for its provision during the trial operation of the GAS PS, a transition was made to the use of electronic technology with the use of electronic signature means, as a result of which the proportion of electronic primary accounting documents received by the GAS PS was $93 \%$. 
The functionality of the state automated system of legal statistics is widely used in the prosecutor's office when preparing analytical documents.

The General Prosecutor's Office of the Russian Federation has prepared a draft standard regulation on the management (department) of legal statistics, information technology and information protection of the prosecutor's office of the constituent entity of the Russian Federation and the specialized prosecutor's office equated to it [19]. This project outlines the management structure, its main tasks and functions, as well as the competence and powers of management employees.

In addition to the designated activities aimed at implementing the Concept, measures are being taken to create appropriate means of identification and authorization, without which it is impossible to use modern information technologies.

In 2018, the certification center of the General Prosecutor's Office of the Russian Federation generated more than 5086 qualified certificates of keys for verifying electronic signatures. Much attention is paid to the protection of departmental information resources. For this purpose, a state system for detecting, preventing and eliminating computer attacks (GosSOPKA) has been created.

Work continues on the main digital transformation services for prosecutorial bodies and organizations.

For example, at a working meeting held in July 2019 at the Prosecutor General's Office of the Russian Federation with representatives of the Voskhod Research Institute for digital transformation, representatives of the Voskhod Research Institute detailed the Prosecutor's Personal Account module, in which it is planned to provide access to automated information systems to an employee of the prosecutor's office. The specified personal account will include the following sections: "Prosecutor's calendar", "Prosecutor's inspections", "Administrative offenses case management", "Intelligent processing of appeals", "Anti-corruption expertise of legal acts", "Service of analysis and reporting on appeals", "Formation of acts of prosecutor's response" and others [20].

\section{CONCLUSIONS}

In general, despite the positive trends in the digitalization of prosecution bodies, it should be noted that it is necessary to improve the qualifications of commissioners for digital transformation in the divisions of the Prosecutor General's Office of the Russian Federation.

In addition, similar modifications need to be done to the prosecutor's offices of the constituent entities of the
Russian Federation and specialized prosecutor's offices equated to them, as well as their maximum involvement in the work of the project office for specialized events. All these steps and provisions would significantly improve the pathway of the informatization of the digital transformation of the prosecutor's office and the organization of its activities in the Russian Federation.

\section{REFERENCES}

[1] D. Brown, S. Toze, Information governance in digitized public administration, Canadian public administration 60(4) (2017) 581-604. DOI: https://doi.org/10.1111/capa.12227

[2] P. Jones, The futures of Canadian governance: Foresight competencies for public administration in the digital era, Canadian public administration 60(4) (2017) 657-681. DOI: https://doi.org/10.1111/capa.12241

[3] D. Cargnello, M. Flumian, Canadian governance in transition: Multilevel governance in the digital era, Canadian public administration 60(4) (2017) 605-626. DOI: https://doi.org/10.1111/capa.12230

[4] C. Hood, A Public Management for all Seasons? Public Administration 69(1) (1991) 3-19. DOI:10.1111/j.1467-9299.1991.tb00779.x

[5] M. Swan, Blockchain. Blueprint for a New Economy, O’Reilly, 2015, 152 p.

[6] Y. Vertakova, E. Leontyev, V. Mkrtchyan, Information provision of decision support systems in conditions of structural changes and digitalization of the economy, Journal of Applied Engineering Science 17(1) (2019) 74-80. DOI: https://doi.org/10.5937/jaes16-18131

[7] D.S. Zuev, A.A. Marchenko, A.F. Khasiannov, Text Mining Tools in Legal Documents, in: L.A. Kalinichenko, Y. Manolopoulos, N.A. Skvortsov, V.A. Sukhomlin (Eds.), Data Analytics and Management in Data Intensive Domains, Collection of Scientific Papers of the $19^{\text {th }}$ International Conference (DAMDID/ RCDL'), MSU, Moscow, 2017, pp. 277-281.

[8] Decree of the President of the Russian Federation dated 09.05.2017 No. 203 "On the Strategy for the Development of the Information Society in the Russian Federation for 2017 - 2030" // SZ RF. 2017. No. 20. Art. 2901.

[9] Order of the Government of the Russian Federation of July 28, 2017 No. 1632-r "On approval of the program" Digital economy of the Russian Federation "// SZ RF. 2017. No. 32. Art. 5138 (no longer valid). 
[10] Order of the Government of the Russian Federation of 12.02.2019, No. 195-r "On recognizing as invalid the order of the Government of the Russian Federation of 28.07.2017, No. 1632-r" // SZ RF. 2019. No. 8. Art. 803.

[11] Passport of the national project "National Program" Digital Economy of the Russian Federation "(approved by the Presidium of the Council under the President of the Russian Federation for Strategic Development and National Projects, Minutes dated 04.06.2019, No. 7) http://www.consultant.ru/ Accessed on 11 Aug 2019

[12] Federal Law of 17.01.1992, No. 2202-1 (as amended on 26.07.2019) "On the Prosecutor's Office of the Russian Federation" // Collected Legislation of the Russian Federation. 1995. No. 47. Art. 4472.

[13] The Prosecutor General's Office of the Russian Federation (2017) Order of the Prosecutor General's Office of Russia dated September 14, 2017 No. 627 "On Approval of the Concept of Digital Transformation of Bodies and Organizations of the Prosecutor's Office until 2025" (together with the "Concept of Digital Transformation of Bodies and Organizations of the Prosecutor's Office of the Russian Federation until 2025") // Legality. 2017. No. 12.

[14] The Prosecutor General's Office of the Russian Federation (2018) Order of the Prosecutor General's Office of the Russian Federation and the Ministry of Telecom and Mass Communications of the Russian Federation of 08.02.2018 No. 68/56 "On approval of the passport of the project for digital transformation of bodies and organizations of the Prosecutor's Office of the Russian Federation" http://www.genproc.gov.ru/documents/orders/document -1331642/ Accessed on 22 Oct 2019

[15] The Prosecutor General's Office of the Russian Federation (2019) Measures for the implementation of measures for the digital transformation of the bodies and organizations of the prosecutor's office of the Russian Federation. http://genproc.gov.ru/smi/news/genproc/news-1595842 Accessed on 20 Oct 2019

[16] The Prosecutor General's Office of the Russian Federation (2017) Order of the Prosecutor General's Office of Russia dated May 16, 2017 No. 346 "On the approval and implementation of the statistical report" On the work of the prosecutor in considering applications, complaints and other appeals "in the form of the $\mathrm{OJ}$ and Instructions for its formation". http://www.consultant.ru/ Accessed on 15 Nov 2018

[17] The Prosecutor General's Office of the Russian Federation (2019) Order of the Prosecutor General's
Office of Russia dated September 19, 2019 No. 665 "On the approval of the Regulations for consideration of appeals from business entities received through a specially created digital platform in connection with the pressure exerted on them by law enforcement agencies". http://www.consultant.ru/ Accessed on 8 Feb 2020

[18] The Prosecutor General's Office of the Russian Federation (2018) The Prosecutor General's Office of the Russian Federation summed up the results of the pilot launch in 27 regions of the state automated system of legal statistics. http://www.genproc.gov.ru/smi/news/genproc/news1355722/ Accessed on 22 Oct 2019

[19] The Prosecutor General's Office of the Russian Federation (2019) Draft Order of the Prosecutor General's Office of Russia "On Approval of the Model Regulations on the Management (Department) of Legal Statistics, Information Technologies and Information Protection of the Prosecutor's Office of the Constituent Entity of the Russian Federation and Equivalent Specialized Prosecutor's Office" (as of 05.07.2019). http://www.consultant.ru/ Accessed 8 Oct 2019

[20] The Prosecutor General's Office of the Russian Federation (2019) At the General Prosecutor's Office of the Russian Federation, a working meeting was held with the representatives for digital transformation of the bodies and organizations of the prosecutor's office of the Russian Federation: The General Prosecutor's Office of the Russian Federation. 29 july 2019. http://genproc.gov.ru/smi/news/genproc/news-1664298 Accessed on 20 Oct 2019 